\title{
APLIKASI PEMBELAJARAN HURUF, ANGKA, WARNA, HEWAN, SAYUR DAN BUAH BERBASIS ANDROID
}

\author{
Aprih Widayanto ${ }^{1}$ Linda Refianti ${ }^{2}$ \\ ${ }^{1}$ Sistem Informasi, STMIK Nusa Mandiri Jakarta, ${ }^{2}$ Teknik Informatika, AMIK BSI Purwokerto \\ e-mail: ${ }^{1}$ aprih.apz@nusamandiri.ac.id, ${ }^{2}$ lindarefianti30@gmail.com
}

\begin{abstract}
Learning is an activity undertaken between teachers and students who need learning components, such as learning objectives, teaching materials, educators, students, teaching aids and learning environments. Learning media can be divided into two printed media and digital media. Seeing the rapid development of technology in which smartphone users from adulthood to early childhood needed a contribution in the world of education in the form of mobile learning media. Early childhood must be given useful knowledge for the development of a mentality that will later be useful to him and the environment. The introduction of letters, numbers, colors, animals, vegetables and fruit is a basic knowledge based learning for children. Teachers and parents in learning basic knowledge of children talking about each material are considered less effective for early childhood. Based on these problems the authors designed the introduction and learning application of letters, numbers, colors, animals, vegetables and fruits with voice speech based on android. This research uses data collection method of observation, and literature study. Results from research and design are implemented into android based learning applications. Features in the app include introductory material and child songs. Based on black box test results, the application is running well.

Keywords: Learning, Learning Media, Learning Based on Android
\end{abstract}

Abstrak - Pembelajaran merupakan aktifitas yang dilakukan antara pengajar dan peserta didik yang membutuhkan komponen-komponen pembelajaran meliputi tujuan pembelajaran, materi pembelajaran, pendidik, peserta didik, media pembelajaran dan lingkungan pembelajaran. Media pembelajaran dapat dibagi menjadi dua yakni media cetak dan media digital. Melihat perkembangan teknologi yang semakin pesat dimana pengguna smartphone dari usia dewasa hingga anak-anak dini tentu memerlukan kontribusi di dunia pendidikan dalam bentuk media pembelajaran mobile. Anak usia dini perlu diberikan pengetahuan yang bermanfaat bagi perkembangan pola pikir yang nanti dapat berguna untuk dirinya dan lingkungan di sekitarnya. Pengenalan huruf, angka, warna, hewan, sayur dan buah adalah pembelajaran pengenalan pengetahuan yang dasar bagi anak usia dini. Guru maupun orangtua dalam memberikan pembelajaran mengenai pengetahuan dasar kepada anak dengan cara mengucapkan masing-masing materi dirasa kurang efektif bagi anak usia dini. Berdasarkan masalah tersebut penulis merancang aplikasi pengenalan dan pembelajaran huruf, angka, hewan, sayur dan buah dengan voicespeech berbasis android. Penelitian ini menggunakan metode pengumpulan data observasi, dan studi pustaka. Hasil dari penelitian dan perancangan diimplementasikan ke dalam aplikasi pembelajaran berbasis android. Fitur-fitur yang terdapat pada aplikasi antara lain materi pengenalan dan lagu-lagu anak. Berdasarkan hasil uji black box, aplikasi tersebut berjalan dengan baik.

Kata Kunci: Pembelajaran, Media Pembelajaran, Pembelajaran Berbasis Android

\section{A. PENDAHULUAN}

Masa anak-anak dalam usia 3-5 tahun, pada usia ini anak senang belajar dan bermain, serta membutuhkan edukasi yang mampu mengembangkan aspek perkembangan anak, meliputi perkembangan kognitif, motorik halus dan kasar, sosial maupun emosional. Edukasitidak serta merta diberikan melalui kegiatan belajar di sekolah oleh guru atau pengajar, namun dapat diperoleh dari aspek lain, seperti pemanfaatan smartphone. Inilah peran orangtua untuk menuntun anak agar memanfaatkan teknologi untuk hal positif. Orang tua tidak harus membatasi dengan lampu merah, melarang anak dengan tegas memainkan smartphone.

Masalah pada anak-anak usia dini yakni terbatasnya pengetahuan dasar, mereka membutuhkan pemahaman mengenai huruf, angka, warna, jenis hewan, nama-nama sayuran dan buah. Pola belajar anak yang senang bermain sangat mempengaruhi konsentrasi anak dalam belajar. Mereka mudah bosan dengan materi teoritis yang disampaikan secara lisan oleh guru maupun orang tua, anak lebih cepat memahami materi berupa gambar dan suara. Oleh karena itu, anak-anak usia dini membutuhkan aplikasi 
edukasi yang dapat membantu dalam proses belajar mereka.

Maksud dari penelitian ini adalah merancang sebuah aplikasi pengenalan dan pembelajaran huruf, angka, warna, hewan, sayur dan buah dengan voice speech berbasis android dan mengimplementasikan aplikasi pengenalan dan pembelajaran huruf, angka, warna, hewan ,sayur dan buah dengan voice speech berbasis android.

Adapun ruang lingkup dalam pembuatan dan penulisan Tugas Akhir ini yakni aplikasi edukasi ini ditujukan untuk anak-anak usia dini sekitar 3-5 tahun, aplikasi ini dibuat menggunakan software B4A dengan dukungan gambar dan suara. Kriteria dalam aplikasi ini meliputi pengenalan huruf, angka, warna, nama-nama hewan, sayuran dan buah dengan voice speech, serta dilengkapi dengan lagulagu anak.

\section{B. TINJAUAN PUSTAKA}

\section{Aplikasi}

Menurut Kamus Besar Bahasa Indonesia dalam Juansyah (2015:2) "Aplikasi adalah penerapan dari rancang sistem untuk mengolah data yang menggunakan aturan atau ketentuan bahasa pemrograman tertentu". Dengan adanya aplikasi pengguna dapat melakukan berbagai aktifitas seperti, melakukan pengolahan data, hiburan, belajar dan aktifitas yang lain.

\section{Program}

Program adalah kata, pernyataan yang disusun menjadi satu kesatuan prosedur yang berupa urutan langkah untuk menyelesaikan masalah dengan menggunakan bahasa pemrograman sehingga dapat dieksekusi oleh komputer (Janti, 2017:106).

\section{Android}

Android adalah sebuah sistem operasi berbasis linux yang ditargetkan berjalan diperangkat telepon pintar, netbooks dan komputer tablet(Maulana, Muhammad, \& Hardiansyah, 2017:120).

\section{Basic4Android(B4A)}

Basic4Android merupakan sebuah tool RAD (Rapid Aplication Developement) yang terdiri dari framework, library, dan IDE yang terintegrasi dengan JAVAdan Android SDK(Sasono, Akrom, \& S, 2015:20).

\section{Corel Draw X7}

Corel Draw X7 atau versi 17 adalah software editor atau designing berbasis vektor yang dirilis oleh Corel Corporation pada tahun 2014. Corel Draw adalah sebuah software program ilustrasi atau editor yang berbasis grafik vektor (Bakti dkk, 2016:32).

\section{Pendidikan}

Pengertian pendidikan berdasarkan Undang-undang No. 20 Tahun 2003, tentang
Sistem Pendidikan Nasional. Pendidikan diartikan sebagai usaha sadar dan terencana untuk mewujudkan suasana belajar dan proses pembelajaran agar peserta didik secara aktif mengembangkan potensi di dalam diri untuk memiliki kekuatan spiritual keagamaan, pengendalian diri, kepribadian, kecerdasan, akhlak mulia, serta keterampilan yang diperlukan dirinya, masyarakat, bangsa, dan Negara.

Pendidikan adalah pengajaran yang berkesinambungan untuk menyampaikan suatu gabungan dari pengetahun, keterampilan, dan pemahaman bagi semua kegiatan kehidupan (UNESCO) dalam (Aqib \& Amrullah, 2017a:1).

\section{Pendidikan Anak Usia Dini}

Pendidikan Anak Usia Dini merupakan upaya pendidik dalam memajukan perkembangan belajar anak sejak lahir sampai dengan usia enam tahun melalui pengalaman dan rangsangan yang bersifat mengembangkan dan terpadu sehingga anakanak dapat berkembang secara optimal sesuai nilai dan norma (Aqib \& Amrullah, 2017b:10).

\section{Flowchart}

Flowchart dalam pemrograman komputer sebagai suatu rencana bangunan yang akan dikerjakan para insinyur (Hardyana, 2016:10).

Flowchart merupakan bagan yang memperlihatkan urutan antar proses dan instruksinya (Muhtar, 2015:28).

Kesimpulan dari teori yang telah dibahas, flowchart adalah rencana sebuah program yang menggambarkan urutan dariprosedur pemecahan masalah yang ditulis dalam simbol-simbol.

\section{Black Box Testing}

Black-Box Testing yaitu menguji perangkat lunak dari segi fungsional untuk mengetahui fungsi-fungsi masukan dan keluaran dari perangkat lunak apakah sesuai dengan spesifikasi yang dibutuhkan(Maulana et al., 2017:21).

a. Keunggulan Black Box Testing

Meskipun dalam pelaksanaan testing kita dapat menguji keseluruhan fungsional perangkat namun formal black box testing yang sebenarnya kita dapat memilih subset test yang secara efektif dan efisien dapat menemukan cacat. Dengan cara ini black box testing dapat membantu memaksimalkan program.

b. Kelemahan Black Box Testing

Pengujian black box memiliki kelemahan ketika tester melakukan black box testing, tester tidak akan pernah yakin apakah perangkat lunak yang diuji telah benarbenar lolos pengujian. Hal ini terjadi karena kemungkinan masih ada beberapa jalur eksekusi yang belum pernah diuji. Untuk 
menemukan cacat perangkat lunak menggunakan black box testing, tester seharusnya membuat setiap kemungkinan kombinasi data input benar.

\section{METODE PENELITIAN}

Metode yang digunakan penulis dalam pencarian dan pengumpulan data sebagai berikut:

1. Observasi

Pada metode ini penulis melakukan observasi atau pengamatan langsung pada objek di R.A Masyithoh Lemberang dan di lingkungan sekitar.

2. Studi Kepustakaan

Pada metode studi pustaka dalam pengumpulan data penulis melakukan dengan membaca literatur-literatur yang berkaitan dengan pembelajaran anak usia dini, dan buku-buku yang berhubungan dengan materi perancangan program.

D. HASIL DAN PEMBAHASAN

1. Analisa Kebutuhan

a. Identifikasi dan Analisa Kebutuhan Pengguna

1) Pengenalan Huruf

Pengguna akan memperoleh pengenalan huruf alfabet dari A-Z.

2) Pengenalan Angka

Pada materi ini pengguna memperoleh pengenalan angka dari 1-20.

3) Pengenalan Warna

Pengguna dikenalkan 12 warna yang terdiri dari merah, kuning, hijau muda, hijau tua, biru muda, biru tua, ungu, putih, hitam, merah muda, jingga dan coklat.

4) Pengenalan Hewan

Pada materi pengenalan hewan, terdapat 3 jenis hewan, terdiri dari hewan unggas, hewan mamalia dan hewan reptil.

5) Pengenalan Sayuran

Pada materi pengenalan sayuran, pengguna akan memperoleh pengenalan 20 nama sayuran.

6) Pengenalan Buah

Pengguna akan memperoleh pengenalan 20 nama buah-buahan.

7) Lagu Anak

Dalam menu ini pengguna dapat mendengarkan 15 lagu-lagu anak.

8) About atau Informasi

Pada menu about pengguna memperoleh informasi tentang aplikasi pembelajaran anak usia dini ini.

b. Analisa Kebutuhan Sistem

1) Kebutuhan perangkat keras (hardware) terdiri dari Processor AMD A6-7310 2.0
GHz, Hardisk500 GB, RAM 6144 MB, monitor 11".

2) Kebutuhan perangkat lunak (software) terdiri dari sistem operasi Windows 10 , Basic4Android (B4A), Corel Draw $X 7$ dan Corel Photo Paint.

\section{Perancangan Algoritma}

Rancangan algoritma aplikasi pembelajaran usia dini ini menggunakan diagram flowchart. Berikut flowchart dari menu utama dan menu materi:

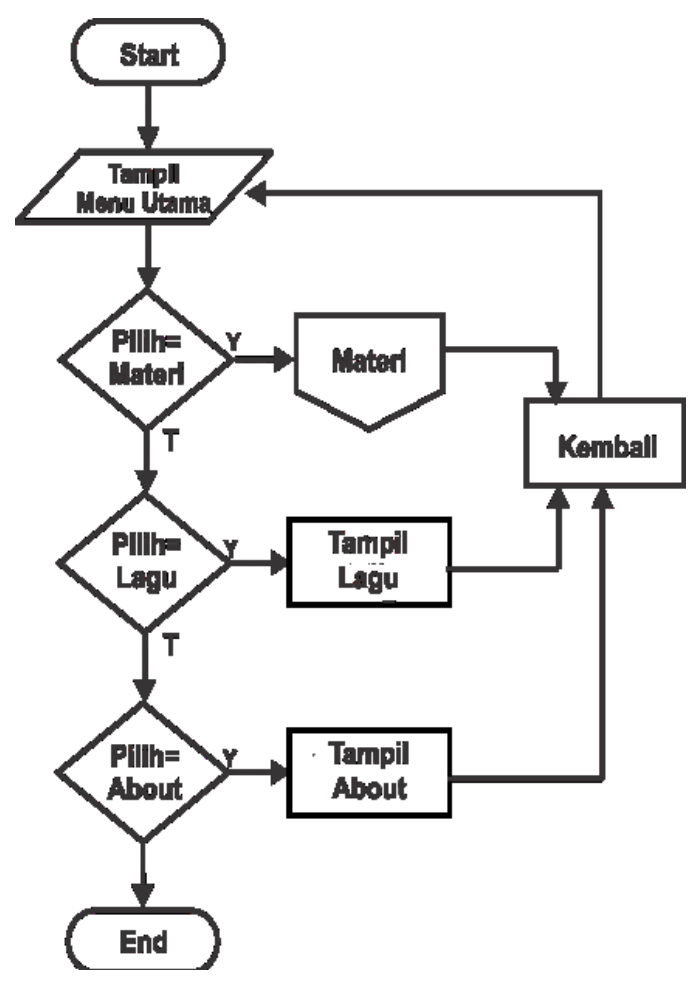

Gambar III.1. Flowchart Menu Utama

Algoritma menu utama ini menjelaskan proses tentang menu yang akan dipilih oleh pengguna. 


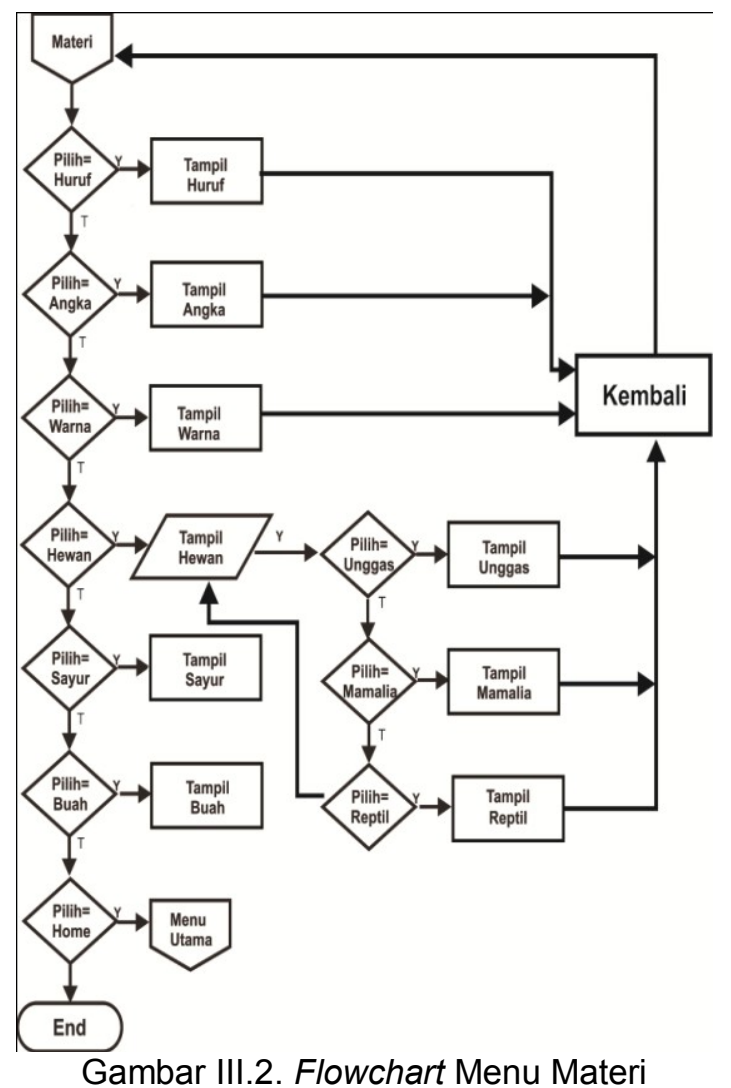

Algoritma menu materi menjelaskan proses pemilihan materi oleh pengguna.

\section{User Interface}

a. User Interface Menu Utama

Pada halaman menu utama terdapat 4 tombol yakni tombol menu materi, tombol lagu anak, tombol about dan tombol speaker.

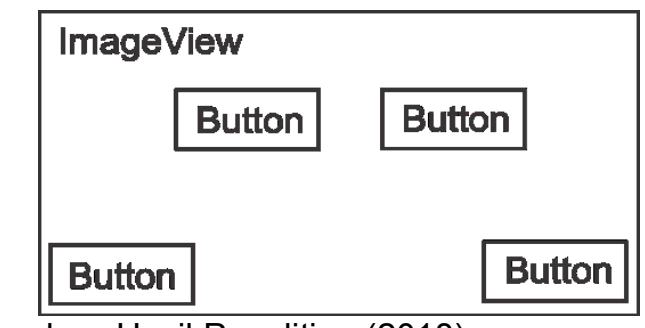

Sumber: Hasil Penelitian (2018)

Gambar III.3. User Interface Menu Utama

b. User Interface Menu Materi

Pada menu materi ada 8 pilihan menu antara lain menu 1 adalah pengenalan huruf, menu 2 adalah pengenalan angka, menu 3 pengenalan warna, menu 4 pengenalan hewan, menu 5 pengenalan sayuran, dan menu 6 pengenalan buah. Serta terdapat tombol speaker dan tombol home.

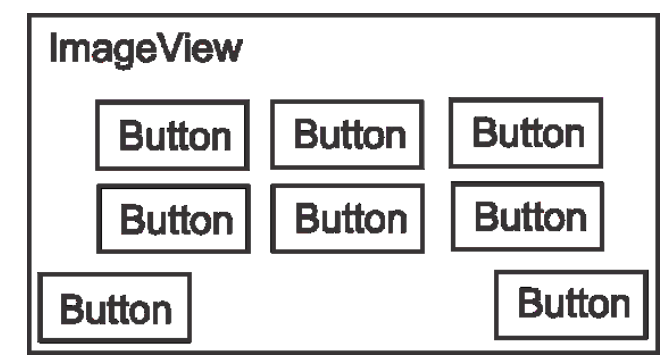

Sumber: hasil Penelitian (2018)

Gambar III.4. User Interface menu Materi

c. User Interface Menu pengenalan Huruf Ketika pengguna memilih menu huruf maka program akan menuju ke halaman pengenalan huruf. Di dalam halaman ini terdapat 28 tombol terdiri dari: A, B, C, D, E, F, G, H, I, J, K, L , M, N, O, P, Q, R, S, T, $\mathrm{U}, \mathrm{V}, \mathrm{W}, \mathrm{X}, \mathrm{Y}, \mathrm{Z}$ dan tombol kembali serta tombol home. Jika pengguna mengklik salah satu tombol angka maka keluar suara angka tersebut.

\begin{tabular}{|c|c|c|c|c|c|c|}
\hline \multicolumn{7}{|c|}{ ImageView } \\
\hline Bution & Button & Button & Buttion & Bution & Bution & Buttion \\
\hline Buthon & Button & Butthon & Buttion & Buithon & Button & Button \\
\hline \multirow[t]{2}{*}{ Buttion } & Button & Buttion & Buttion & Bution & Button & Button \\
\hline & Buttion & Bution & Bution & Buttion & Buttion & \\
\hline Button & & & & & & Button \\
\hline
\end{tabular}

Sumber: Hasil Penelitian (2018)

Gambar III.5. User Interface Menu Pengenalan Huruf

d. User Interface Menu Pengenalan Angka Ketika pengguna memilih menu huruf maka program akan menuju ke halaman pengenalan huruf. Di dalam halaman ini terdapat 22 tombol yang terdiri dari: 1, 2, 3, $4,5,6,7,8,9,10,11,12,13,14,15,16$, 17, 18, 19, 20, kembali dan home. Jika pengguna mengklik salah satu tombol angka maka keluar suara angka.

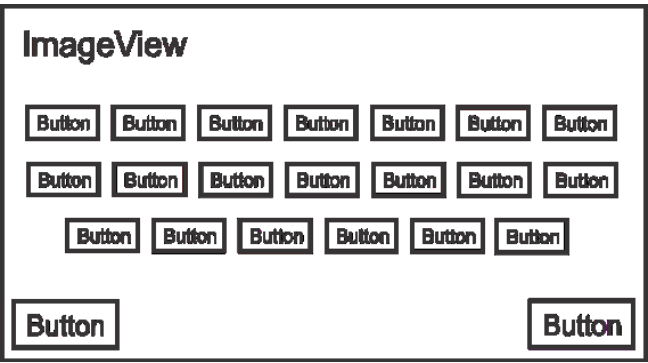

Sumber: Hasil Penelitian (2018)

Gambar III.6. UserInterface Menu Pengenalan Angka

e. User Interface Menu Pengenalan Warna 
Ketika pengguna memilih menu warna maka program akan menuju ke halaman pengenalan warna. Di dalam halaman ini terdapat 14 tombol terdiri dari: warna merah, kuning, hijau muda, hijau tua, biru muda, biru tua, ungu putih, merah muda, hitam, coklat, jingga dan tombol kembali serta tombol home. Jika pengguna mengklik salah satu tombol warna maka keluar suara warna tersebut.

\begin{tabular}{|c|c|c|c|c|c|}
\hline \multicolumn{6}{|c|}{ ImageView } \\
\hline Bution & Button & Button & Button & Button & Button \\
\hline Button & Button & Button & Button & Button & Button \\
\hline Button & & & & & Button \\
\hline
\end{tabular}

Sumber: Hasil penelitian (2018)

Gambar III.7. User Interface Menu Pengenalan Warna

f. User Interface Menu Pengenalan Hewan Ketika pengguna memilih menu hewan. maka program akan menuju ke halaman menu jenis hewan. Di dalam halaman ini terdapat 5 tombol, tombol pengenalan hewan unggas, hewan mamalia, dan hewan reptil serta tombol kembali, tombol home.

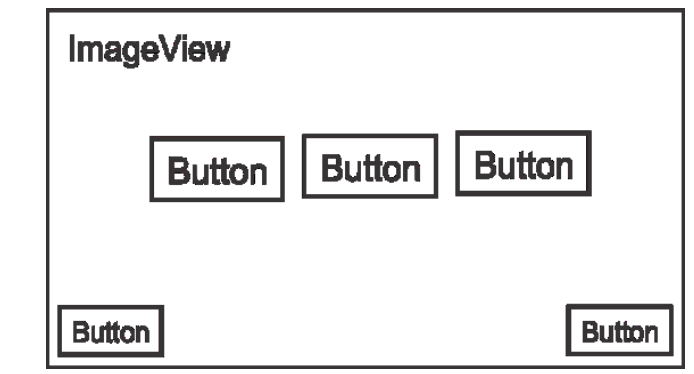

Sumber: Hasil penelitian (2018)

Gambar III.7. User Interface Menu Pengenalan Hewan

g. User Interface Menu Pengenalan Hewan Unggas

Ketika pengguna memilih menu warna maka program akan menuju ke halaman pengenalan warna. Di dalam halaman ini terdapat 12 tombol terdiri dari: hewan ayam, bebek, angsa, elang, bangau, merak, kalkun, kasuari, belibis, entok dan tombol kembali serta tombol home. Jika pengguna mengklik salah satu tombol hewan maka keluar suara nama hewan unggas tersebut.

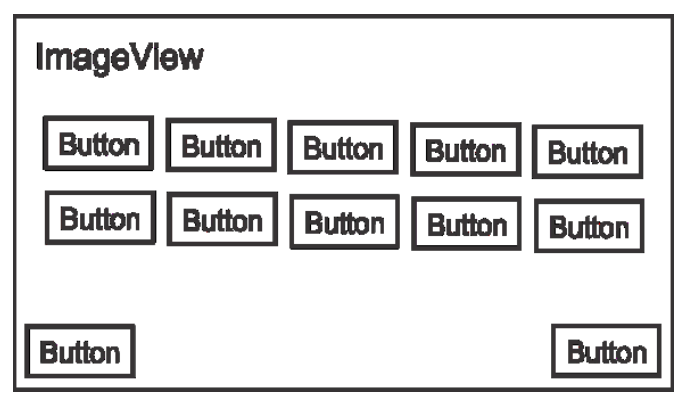

Sumber: Hasil Penelitian (2018)

Gambar III.9. User Interface Pengenalan Hewan Unggas

h. User Interface Pengenalan Hewan Mamalia Saat pengguna memilih menu warna maka program akan menuju ke halaman pengenalan warna. Pada halaman ini terdapat 12 tombol yang terdiri dari: hewan kelinci, kucing, sapi, kerbau, kambing, domba, kuda, rusa, gajah, jerapah dan tombol kembali serta tombol home. Jika pengguna mengklik salah satu tombol hewan maka keluar suara nama hewan mamalia tersebut.

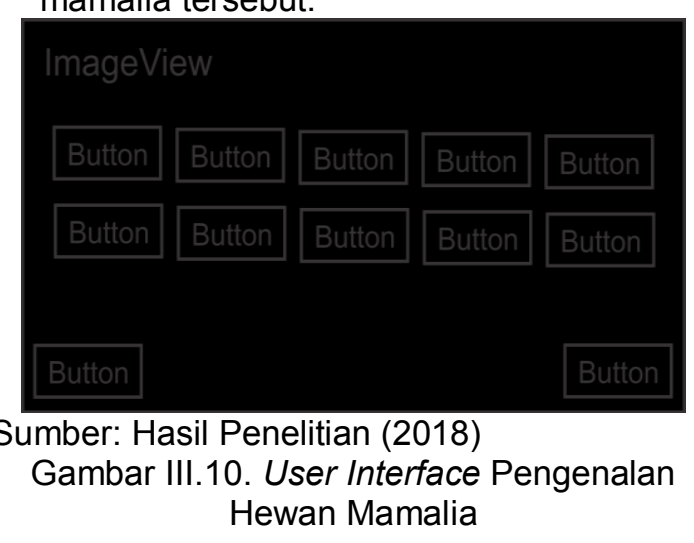

i. User Interface Pengenalan Hewan Reptil Di dalam halaman ini terdapat 12 tombol, terdiri dari: hewan ular, buaya, komodo, kadal, iguana, cicak, tokek, kura-kura, penyu, bunglon dan tombol kembali serta tombol home.

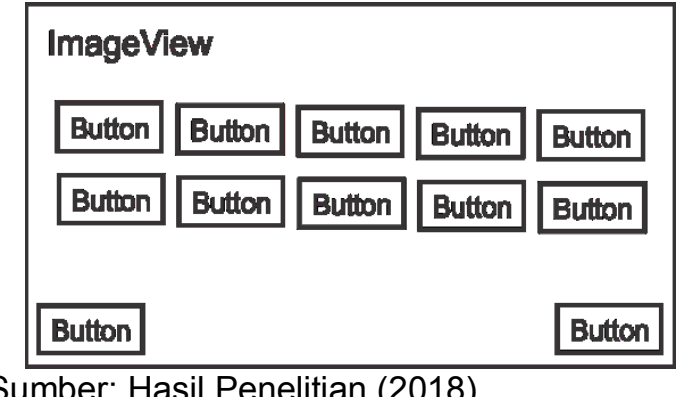

Sumber: Hasil Penelitian (2018)

Gambar III.11. User Interface Pengenalan Hewan Reptil 
j. User Interface Pengenalan Buah

Saat pengguna memilih menu buah, maka program akan menuju ke halaman pengenalan buah. Di dalam halaman ini terdapat 22 tombol, background. Untuk tombol terdiri dari: buah apel, jeruk, anggur, stroberi, nanas, kiwi, sirsak, pisang, pepaya, mangga, durian, rambutan, belimbing, jambu, manggis, semangka, melon, leci, salak, ceri dan tombol kembali serta tombol home.

\section{ImageView \begin{tabular}{|l|l|l|l|l|l|}
\hline Button & Button & Button & Button & Button & Button \\
\hline
\end{tabular} \begin{tabular}{|l|l|l|l|l|l|}
\hline Button & Buttion & Button & Button & Button & Button \\
\hline
\end{tabular} \begin{tabular}{|l|l|l|l|l|}
\hline Button & Button & Button & Button & Button \\
\hline
\end{tabular} Button Button \\ Sumber: Hasil Penelitian (2018) \\ Gambar III.12. User Interface Pengenalan Buah}

k. User Interface Pengenalan Sayuran

Di dalam halaman ini terdapat 22 tombol yang terdiri dari: sayur wortel, tomat, sawi, kubis, buncis, brokoli, kentang, labu, bayam, timun, lobak, jamur, cabai, selada, terong, seledri, paprika, daun bawang, asparagus, bawang bombay dan tombol kembali serta tombol home.

\begin{tabular}{|c|c|c|c|c|c|}
\hline \multicolumn{6}{|c|}{ ImageView } \\
\hline Button & Button & Button & Button & Button & Button \\
\hline \multirow{2}{*}{$\begin{array}{r}\text { Button } \\
\text { B }\end{array}$} & Button & Button & Button & Button & Button \\
\hline & iutton & \multicolumn{2}{|c|}{ Button } & itton $B$ & Button \\
\hline \multicolumn{5}{|l|}{ Button } & Button \\
\hline
\end{tabular}

Sumber: Hasil Penelitian (2018)

Gambar III.13. User Interface Pengenalan Sayuran

I. User Interface Menu Lagu Anak

Pengguna dapat memilih lagu yang sudah disediakan berupa list-list. Di halaman ini terdapat 3 tombol yang terdiri dari tombol home, tombol play, tombol stop dan satu listview.

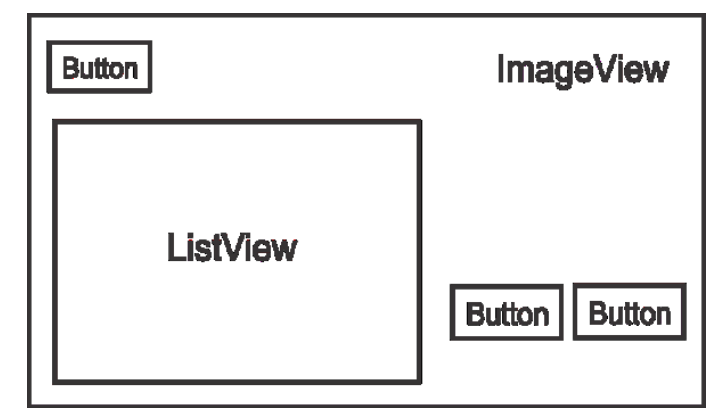

Sumber: Hasil Penelitian (2018)

Gambar III.14. User Interface Menu Lagu Anak

\section{Implementasi}

Penulis melakukan implementasi dengan menggunakan software Basic4Android (B4A). Berikut adalah tampilan dari aplikasi yang telah dirancang.

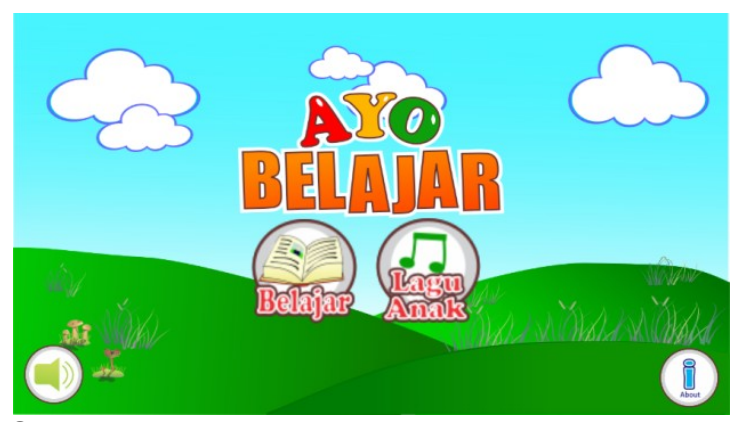

Sumber: Hasil Penelitian (2018)

Gambar III.15. Tampilan Menu Utama

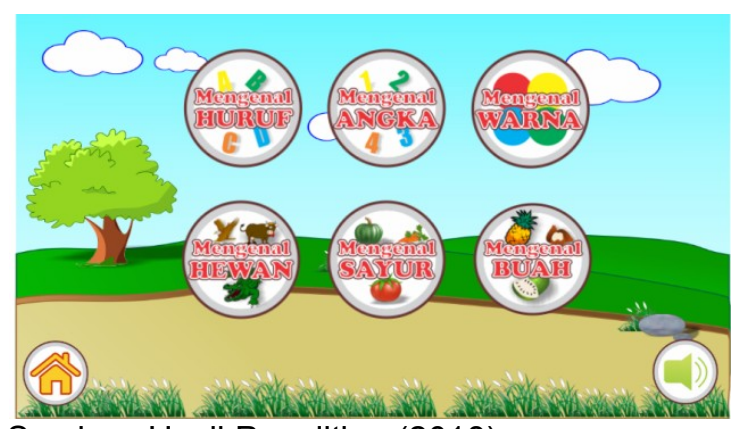

Sumber: Hasil Penelitian (2018)

Gambar III.16. Tampilan Menu Materi

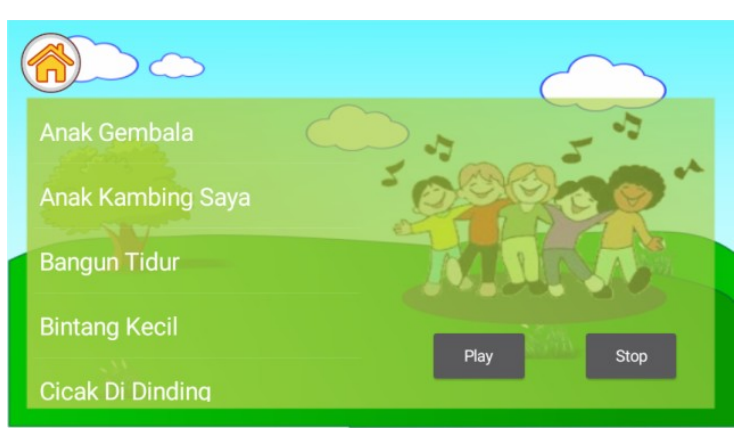

Sumber: Hasil Penelitian (2018)

Gambar III.17. Tampilan Menu Lagu Anak 


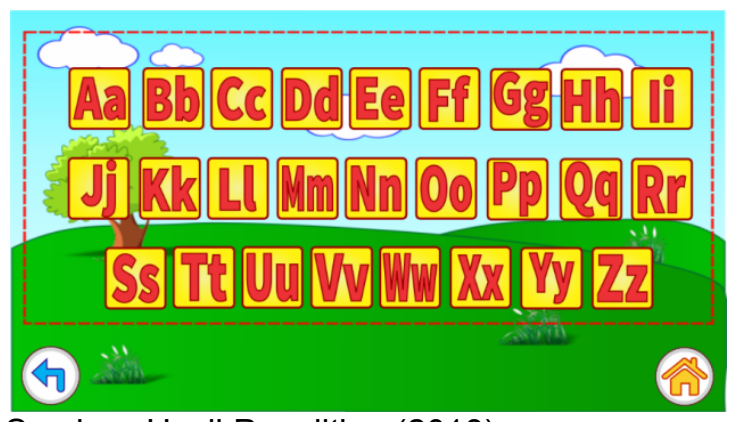

Sumber: Hasil Penelitian (2018)

Gambar III.18. Tampilan Pengenalan Huruf

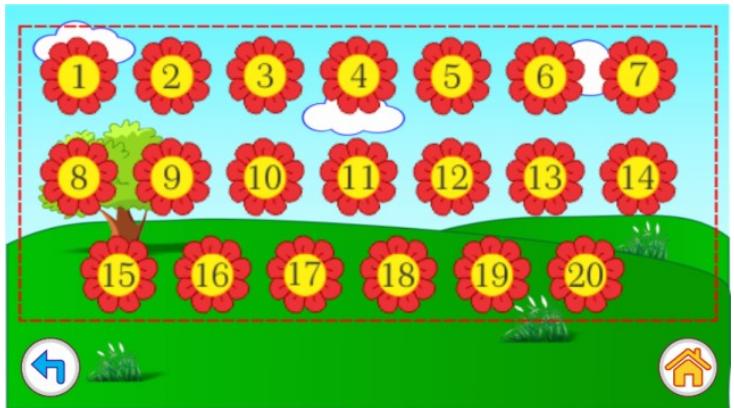

Sumber: Hasil Penelitian (2018)

Gambar III.19. Tampilan Pengenalan Angka

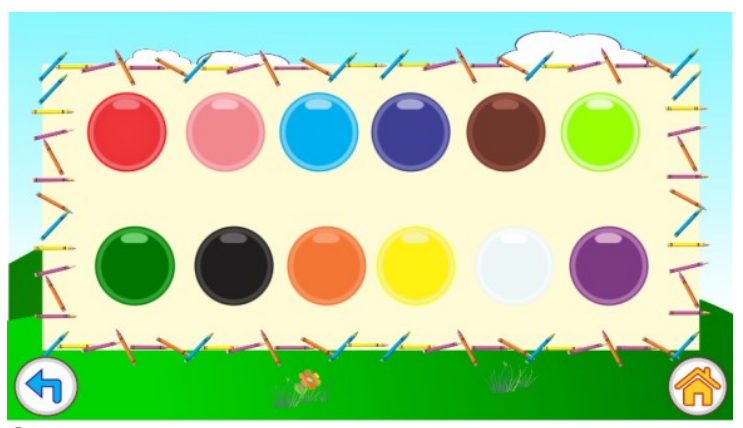

Sumber: Hasil Penelitian (2018)

Gambar III.20. Tampilan Pengenalan Warna

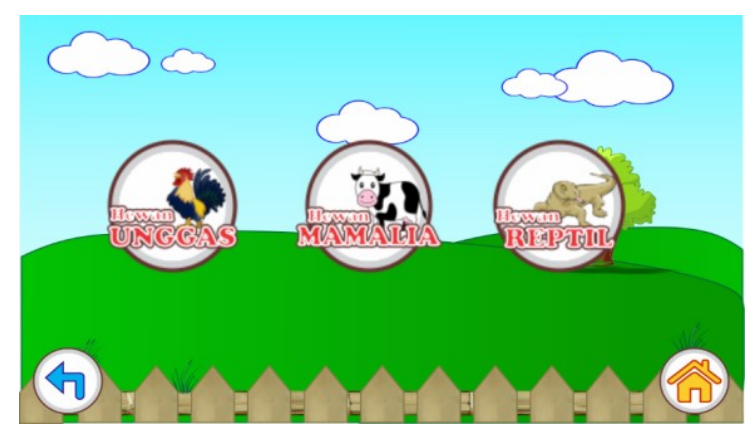

Sumber: Hasil Penelitian (2018)

Gambar III.21. Tampilan Menu Hewan

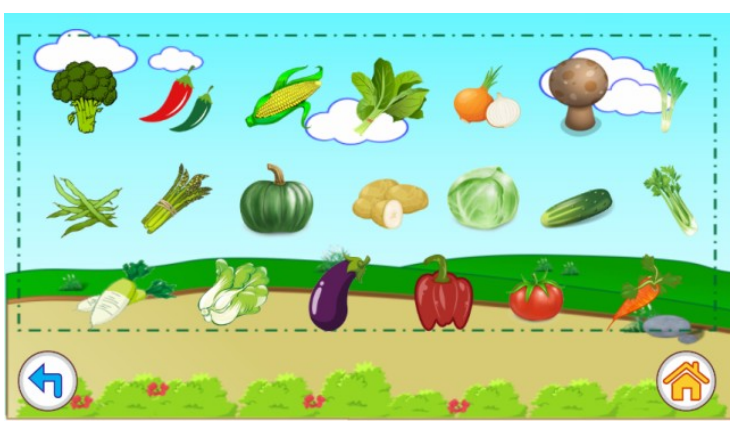

Sumber: Hasil Penelitian (2018)

Gambar III.22. Tampilan Pengenalan Sayuran

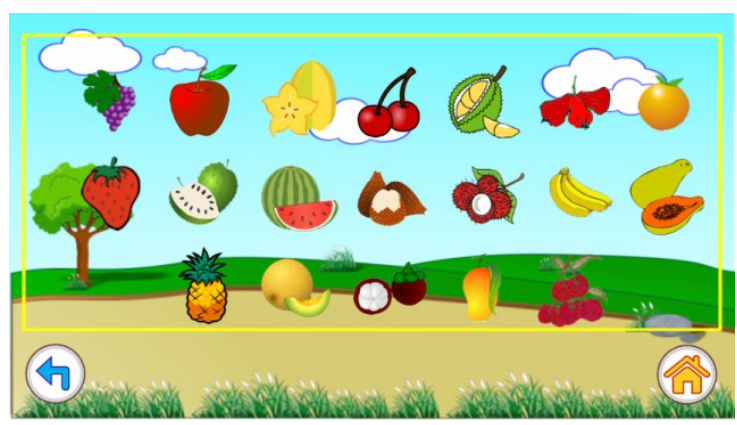

Sumber: Hasil Penelitian (2018)

Gambar III.23. Tampilan Pengenalan Buahbuahan

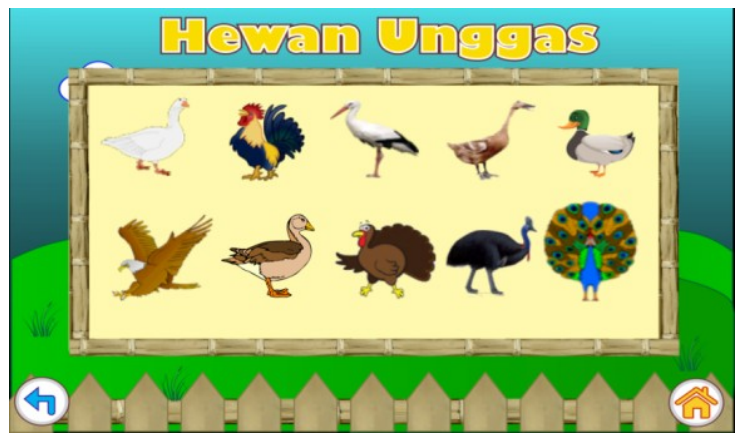

Sumber: Hasil Penelitian (2018)

Gambar III.24. Tampilan Pengenalan Hewan Unggas

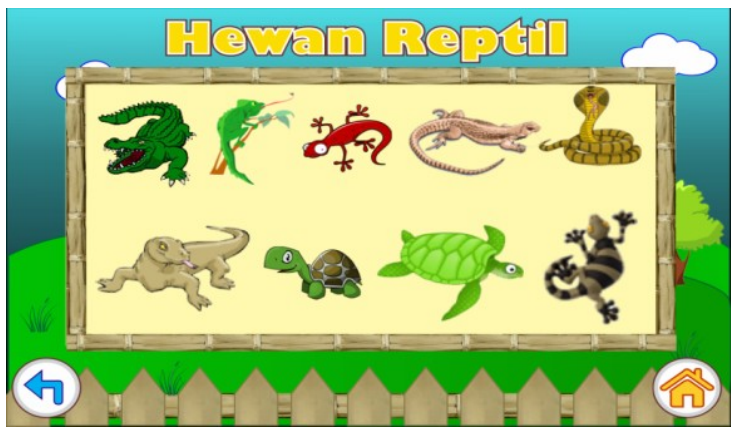

Sumber: Hasil Penelitian (2018)

Gambar III.25. Tampilan Pengenalan Hewan Reptil 


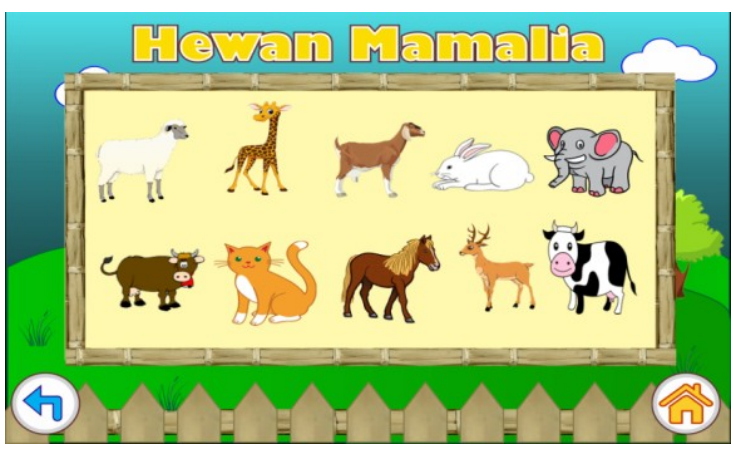

Sumber: Hasil Penelitian (2018)

Gambar III.26. Tampilan Pengenalan Hewan Mamalia

\section{Testing}

Dalam merancang aplikasi pembelajaran anak usia dini dilakukan pengujian menggunakan Black Box Testing. Berikutini adalah table pengujian black box aplikasi pengenalan dan pembelajaran huruf, angka, warna, hewan, sayur dan buah:

Tabel III.9.

Pengujian Black Box

\begin{tabular}{|c|c|c|c|c|}
\hline 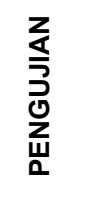 & 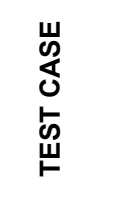 & 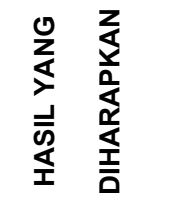 & 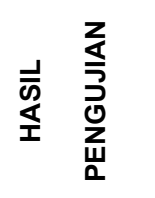 & $\frac{\infty}{\frac{2}{5}}$ \\
\hline $\begin{array}{l}\text { Tomb } \\
\text { ol } \\
\text { About }\end{array}$ & $\begin{array}{l}\text { Klik } \\
\text { tombol } \\
\text { about } \\
\text { di } \\
\text { menu } \\
\text { utama } \\
\end{array}$ & $\begin{array}{l}\text { Pengguna } \\
\text { dapat } \\
\text { melihat } \\
\text { informasi } \\
\text { tentang } \\
\text { aplikasi }\end{array}$ & $\begin{array}{l}\text { Menampi } \\
\text { lkan } \\
\text { informasi } \\
\text { tentang } \\
\text { aplikasi }\end{array}$ & OK \\
\hline $\begin{array}{l}\text { Tomb } \\
\text { ol } \\
\text { Menu } \\
\text { Belaj } \\
\text { ar }\end{array}$ & $\begin{array}{l}\text { Klik } \\
\text { tombol } \\
\text { Belajar } \\
\text { di } \\
\text { menu } \\
\text { utama }\end{array}$ & $\begin{array}{l}\text { Pengguna } \\
\text { dapat } \\
\text { melihat } \\
\text { menu } \\
\text { materi }\end{array}$ & $\begin{array}{l}\text { Menampi } \\
\text { Ikan } \\
\text { Menu } \\
\text { materi } \\
\text { pengenal } \\
\text { an huruf, } \\
\text { angka, } \\
\text { warna, } \\
\text { hewan, } \\
\text { sayur } \\
\text { dan } \\
\text { buah }\end{array}$ & OK \\
\hline $\begin{array}{l}\text { Tomb } \\
\text { ol } \\
\text { Menu } \\
\text { Lagu }\end{array}$ & $\begin{array}{l}\text { Klik } \\
\text { tombol } \\
\text { lagu } \\
\text { anak di } \\
\text { menu } \\
\text { utama }\end{array}$ & $\begin{array}{l}\text { Pengguna } \\
\text { dapat } \\
\text { melihat } \\
\text { halaman } \\
\text { lagu-lagu } \\
\text { anak }\end{array}$ & $\begin{array}{l}\text { Menampi } \\
\text { Ikan } \\
\text { menu } \\
\text { lagu } \\
\text { anak }\end{array}$ & OK \\
\hline $\begin{array}{l}\text { Tomb } \\
\text { ol } \\
\text { Kemb } \\
\text { ali }\end{array}$ & $\begin{array}{l}\text { Klik } \\
\text { tombol } \\
\text { Kembal } \\
\mathrm{i}\end{array}$ & $\begin{array}{l}\text { Pengguna } \\
\text { dapat } \\
\text { menekan } \\
\text { tombol } \\
\text { kembali } \\
\text { untuk } \\
\text { kembali ke }\end{array}$ & $\begin{array}{l}\text { Kembali } \\
\text { ke menu } \\
\text { materi }\end{array}$ & OK \\
\hline
\end{tabular}

\begin{tabular}{|l|l|l|l|l|}
\hline & & $\begin{array}{l}\text { menu } \\
\text { materi }\end{array}$ & \\
\hline $\begin{array}{l}\text { Tomb } \\
\text { ol } \\
\text { Home }\end{array}$ & $\begin{array}{l}\text { Klik } \\
\text { tombol } \\
\text { home }\end{array}$ & $\begin{array}{l}\text { Pengguna } \\
\text { menekan } \\
\text { tombol } \\
\text { home untuk } \\
\text { kembali ke } \\
\text { menu } \\
\text { utama }\end{array}$ & $\begin{array}{l}\text { Kembali } \\
\text { ke menu } \\
\text { utama }\end{array}$ & OK \\
\hline $\begin{array}{l}\text { Tomb } \\
\text { ol } \\
\text { Close }\end{array}$ & $\begin{array}{l}\text { Klik } \\
\text { tombol } \\
\text { close }\end{array}$ & $\begin{array}{l}\text { Pengguna } \\
\text { dapat keluar } \\
\text { program }\end{array}$ & $\begin{array}{l}\text { Keluar } \\
\text { program }\end{array}$ & OK \\
\hline
\end{tabular}

Sumber: Hasil Penelitian (2018)

\section{E. KESIMPULAN}

Dari pembahasan yang telah dikemukakan sebelumnya, penulis memperoleh kesimpulan sebagai berikut:

1. Hasil dari penelitian ini adalah terciptanya aplikasi pengenalan dan pembelajaran huruf, angka, warna, hewan, sayur dan buah dengan voice speech berbasis android.

2. Aplikasi pembelajaran anak usia dini memberi pengetahuan pengenalan huruf, angka, warna, hewan, sayur dan buah dengan tampilan yang menarik, sehingga anak lebih termotivasi untuk belajar dan lebih mudah menerima pengetahuan tentang materi tersebut.

3. Aplikasi pembelajaran anak usia dini dijadikan sebagai sarana belajar dan hiburan untuk anak dikarenakan selain adanya materi pembelajaran terdapat juga lagu-lagu anak.

4. Aplikasi pembelajaran anak usia dini membantu proses belajar yang efisien dan efektif.

Adapun saran untuk pengembangan lebih lanjut aplikasi pembelajaran anak usia dini ini adalah sebagai berikut:

1. Untuk pengembangan aplikasi perlu ditambahkan game edukasi.

2. Memperbanyak materi dengan membuat level, misalkan dari level dasar hingga level lanjut.

3. Ditambahkan media latihan menulis untuk anak. 


\section{DAFTAR PUSTAKA}

Aqib, Z., \& Amrullah, A. 2017. Ensiklopedia Pendidikan dan Psikologi. Andi, Yogyakarta.

Bakti, S., Hasibuan, N. A., Sianturi, L. T., \& Sianturi, R. D. 2016. Perancangan Aplikasi Pembelajaran Coreldraw X3 Menggunakan Metode Web Based Learning $(\mathrm{Wbl})$. Jurnal Riset Komputer, 3(4), 32-35. http://stmikbudidarma.ac.id/ejurnal/index.php/juriko m/article/download/336/286

Hardyana, S. E. 2016. Pulau Indonesia Berbasis Android Pada Tk Kupu-Kupu Mungil Bekasi. Jurnal Teknik Komputer, 2(1), 9-21. http://ejournal.bsi.ac.id/ejurnal/index.php/j tk/article/viewFile/358/267

Juansyah, A. 2015. Pembangunan Aplikasi Child Tracker Berbasis Assisted - Global Positioning System ( A-Gps ) Dengan Platform Android. Jurnal IImiah Komputer dan Informatika ( KOMPUTA ). 1. http://elib.unikom.ac.d/files/disk1/673/jbpt unikompp-gdl-andijuansy-33648-1120.unik-a.pdf

Maulana, M. S., Muhammad, A., \& Hardiansyah, F. 2017. Media Pembelajaran Pengenalan HewanHewan Khas Kalimantan Berbasis Android Mobile Learning ( Studi Kasus: TK Aisyiyah Bustanul Athfal 5 ). Jurnal Khatulistiwa Informatika, V(2), 119-127. http://ejournal.bsi.ac.id/ejurnal/index.php/ khatulistiwa/article/viewFile/2888/1871

Muhtar, M. S. 2015. Aplikasi Pengelola Keuangan Pribadi Dan Rumah Tangga Berbasis Android. Uin Alauddin Makasar. http://repositori.uinalauddin.ac.id/2391/1/muthmah sutrisna muhtar.pdf

Sasono, S. H. W., Akrom, R. Al, \& S, R. M. 2015. Optimalisasi Smartphone Untuk Kontrol Dan Monitor Air Conditioner Pada Shelter Starone Semarang, 13(1), 19-24. http://download.portalgauda.org/article.ph p?article $=443222 \&$ val $=9320 \&$ title $=$ Optim alisasi Kontrol Dan Monitor Air Conditioner Pada Shelter Starone Semarang

Suhar Janti. 2017. Animasi Edukasi Interaktif Tes Kemampuan Konsentrasi Dengan Permainan Tebak Warna, III(1), 106-113. http://ejournal.bsi.ac.id/ejurnal/index.php/j 